TECHNICAL SCIENCES AND TECHNOLOGIES

UDC 621.865 .8

DOI: $10.25140 / 2411-5363-2021-2(24)-49-54$

Rudolf Jánoš, Srikanth Murali

\title{
DESIGN OF BALL COLLECTING ROBOT
}

A concept of four-wheeled mobile service robot capable of collecting balls from the Tennis court is proposed in this article. The robot is capable of manoeuvring on its own in an autonomous way and also it can be operated wirelessly. The robot is built using the Arduino Uno R3 microcontroller board along with sensors like LiDAR, ultrasound sensor, optical encoders, infrared sensor, camera for vision system. Sensor fusion can be implemented for localization of the robot while detection of the tennis ball can be attained by learning based object detection algorithm using OpenCV. A* algorithm is proposed for the navigation of the robot towards the object. Wireless operation of the robot can be achieved with the Bluetooth technology using the Android application via a smartphone.

The article is an overview and information.

Keywords: Four-wheeled service robot; sensor fusion; ball-collecting robot; Arduino Uno R3 microcontroller board; Wireless control using the Bluetooth technology.

Fig.: 2. References: 11.

Urgency of the research. The automation of service activities is gradually expanding into the field of sports equipment, which allows you to automate routine activities. This article describes the design of a robot for collecting balls on a tennis court. The main purpose of this section is to provide information on the recent trends that are involved in the development of a mobile service robot capable of operating both indoor and outdoor environment. The important consideration while developing a service robot are the selection of chassis, control of the robot movement, types of controlling and navigation [3].

Target setting. The article comprises of the different stages involved in the development of a full-autonomous robot, which are: 1) design of a robot, with its main part description; 2) localization of the robot, which is the most important and difficult task in an autonomous robot work; 3) finally, detection of object and obstacle, which involves the detection of a tennis ball which is the object, and other obstacles that hinder the maneuverability of the robot. Also, a semi-autonomous control of the robot is proposed, which allows control and commands to be transmitted wirelessly and the robot can operate by the user's request. A separate application for the Android platform can be used for sending the navigation commands to the robot using the Bluetooth technology [2].

Actual scientific researches and issues analysis. The robot's task is to collect balls from a tennis court at various occasions thereby saving user's time and effort. The mode of operation of the robot can be fully autonomous or semi-autonomous in which it can be controlled by a smartphone using the Bluetooth Technology. An Android app can be installed on a smartphone consisting of the buttons for choosing the mode of operation and for navigating the robot in case it is driven by an operator. The command signals from the smartphone application are transmitted to the mobile robot. The robot is installed with Bluetooth module which can be used to receive the control commands and perform the operation. The robot can be used in place of a human for collecting the balls and thus human's time and efforts are saved which can be invested into additional practicing [4].

Analysis of existing research and publications. The description of the existing solutions will be divided according the main components of the robots.

\section{Chassis}

The main consideration of a service robot is its chassis. The chassis is the structural component which accommodates a drivetrain and wheels. The chassis can also be referred to as the skeleton of the robot. It acts as a base for connecting manipulators like arms, object intakes, blowers, etc. The chassis should be durable, lightweight, cost effective and easily available in market. A perfect robot chassis can be selected based on the following:

Material - the material of the chassis can be selected based on the robot's activity. Some of the materials are wood, 3d-printed plastic, acrylic, metal (steel, aluminium or alloy) or composites.

(C) Jánoš R., Murali S., 2021 
Purpose - the prime use of the robot, its working environment, nature of work of the robot are all need to be considered.

Size - the size depends on the application where the robot will be used and also the components it will be installed with.

Shape - the chassis shape must accommodate the other components like motors, wheels, control systems, etc. and so it has to be of good design [5].

\section{Control of Movement}

The control of robot movement purely depends upon the type of the robot and its working environment. For example, a floor cleaning robot has to reach every point of the floor and also it should not move on the same area repeatedly. While, a surveillance robot has to reach main areas and gather the information. Some of the wheeled robots follow a different type of kinematics called the differential drive system. This drive system is designed in a way that the robot movement is carried out on the powered individual wheels of the robot. The working of the differential drive mechanism is as follows:

The system hosts two powered wheels, each on one side of the robot. In case of four-wheel robots, the two motors on one side are connected in parallel such that the motors on each side of the robot are driven separately. Straight movement of the robot can be achieved if the motors on both sides of the robot rotate with same speed and in the same direction. Turning can be achieved if one side of the wheels spins faster than the other side. The direction of the turn will be towards the side where wheels rotate at a slower speed. This turning is similar to the normal turning of an automobile, i.e., in a curved manner. If the direction of rotation of wheels on one side is opposite to the direction of rotation of the other side wheel, then the robot performs a turn within its place. This is similar to the rotation of the robot [6].

The differential drive robot poses a complication while moving in a straight line. This is due to the difference in the rate of turning of the wheels whose drives are independent. Factors like friction differences in drivetrain, friction differences between the wheel and the surface, and slight differences in the motor affect the turning of the drive motors at same rate. In order to achieve this, the motor RPM can be adjusted many times per second which may require interrupt-based software and assembly language programming. Another way to achieve this is the use of encoders for determining the accurate position of the wheels.

\section{Classification based on controlling}

In general, a robotic movement is constructed on the basic rule consisting of three questions [2]. They are: (1) Where am I now? (2) Where do I want to go? (3) How do I get there? By finding answers for these questions, the movement of a robot is successfully obtained. For example, the answer for question "where am I now?" can be determined with the help of sensors as the surrounding of a robot will be potentially varying and the sensors help to identify the presence of obstacles, objects, etc. Coming to the second question "Where do I want to go?", the answer depends on the task that is to be performed by the robot - a starting point and an end point can be used for depicting the movement of the robot from one place to another. And for the final question "How can I get there?", the assistance of localized path guidance system and a global motion planar system are required to reach a target. The robot's path is determined by tracking points generated from the environment.

The above is the basic ideology for controlling any conventional robot. Apart from this, the robots based on the control type are classified as semi-automatic, automatic, tele operated, cloud operated etc.

\section{Navigation}

The most important thing for any mobile device is its ability to navigate with respect to its environment. Robot navigation is the process of determining the own position of the robot and guide its path towards a specific location. Some robots use a different approach for navigation 
called reactive navigation in which the robot reacts directly to its environment. For example, a wall follower robot follows the wall and thus moves from one position to another. This is the same in case of a firefighting robot in which the robot senses the fire using a flame sensor, navigates itself towards the fire and thus sprays water to put off the fire. Autonomous robots are capable of navigating on its own by sensing its surroundings and they need no guidance, for example, the Autonomous Mobile Robot (AMR). Semi-automatic robots, on the other hand, require guidance for navigating them along a pre-defined path or user's defined direction. The Autonomous Guided Vehicle (AGV) is a perfect example for a robot requiring guidance [7].

Article objective. The basic idea of why it was necessary to implement the simulation in the environment was to show the steps needed to successfully master the environment. There is a total of three different workplaces in the robot's workspace.

\section{General overview of the system.}

The work in this section involves the designing of the robot and the ball-collecting mechanism. The design is performed on CATIA V5 software in a simple way for representation of the robot. Aluminium is the material of choice for the robot chassis due to its lightweight and corrosive resistant properties. The robot consists of the chassis part on which it is built. The special mechanism for collecting the balls from the surface of the tennis court is attached to the front of the chassis. Once the robot navigates itself near the ball, the ball-collecting mechanism does its job in retrieving it and stores it in the storage compartment located to the rear part of the robot. The operation of the mechanism is analogous to the mechanism for the ball shooting found in a tennis ball machine. It consists of two rolling wheels placed perpendicular to the ground. The rolling wheels are placed at a distance which will be enough for a tennis ball to pass through. The wheels are rotated in a direction opposite to each other by electric motors and whenever the ball gets in contact with the rotating wheels it is forced inwards due to the instantaneous velocity developed by the rotation of the wheels. This instantaneous velocity is enough for the ball to reach the storage container where it gets projected in air due to the inclined path of its travel.

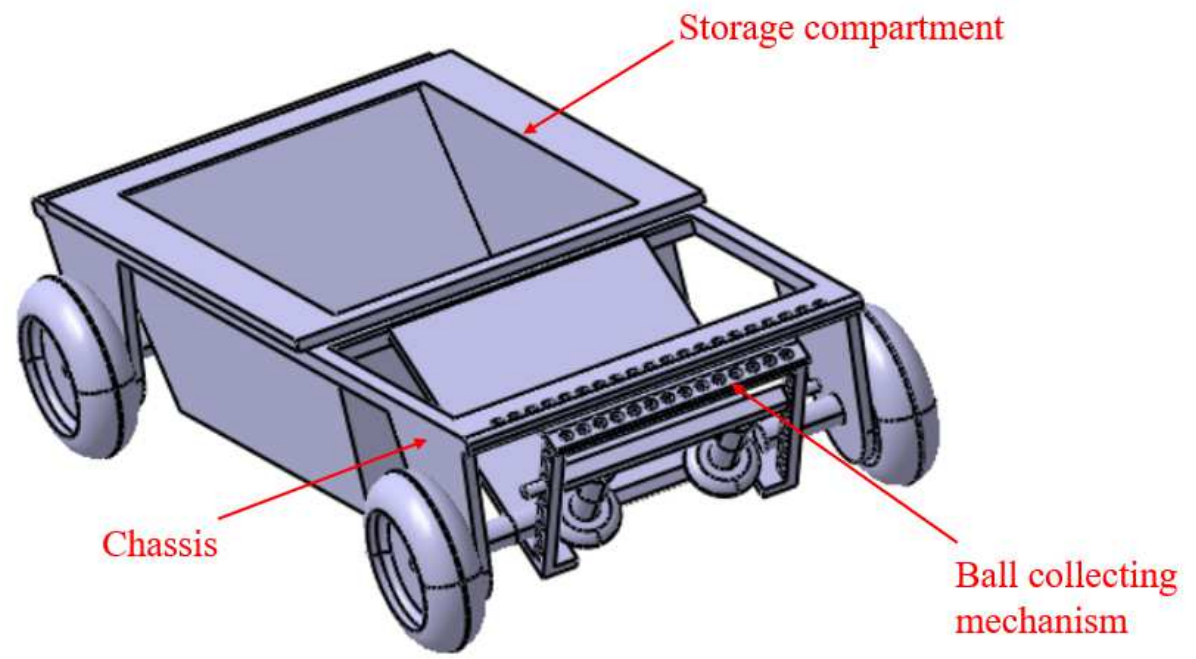

Fig. 1. Annual procurement of industrial robots in the thousands

Localization of the robot is the initial and the most complex task in achieving the autonomous navigation of the robot. The robot has to locate itself in order to perform the path-tracking and planned navigation in any given surroundings. The mission objective of the robot is made possible with the localization of the robot in its environment. The position of the robot keeps changing over time and so does an environment. Therefore, it is crucial for the robot to keep 
track of its movement and its surroundings throughout its workflow. The initial step of the process is the self-localization of the robot which can be determined with the help of different types of sensors. These sensors detect the surroundings and the data from these sensors are used in determining the position of the robot. The robot keeps updating its location in a map whenever it manoeuvres on the ground so that the end point of the robot is attained efficiently. Once the robot positioning is done, the robot can track the object and plans multiple paths to reach its target and thus the autonomous navigation of the robot is performed [11].

The proposed method of self-localization of the robot can be achieved with the help of sensors like optical encoders and LiDAR sensor. The positioning of the robot with the use of optical encoders is called dead-reckoning system. This is an open-loop estimation of the position of the robot in which the encoders are available for the control of the motor which in turn provides the actual angular displacement of the wheels. The distance covered by the robot can be determined with the help of rotary encoders and is given by,

$$
\text { distance travelled }=\text { wheel circumference } \cdot \frac{\text { counts }}{\text { (number of counts per revolution })} \text {. }
$$

However, errors may arise due to the surface roughness, mechanical tolerances or wheel slip which gets incremented with time resulting in poor positioning of the robot. In a way to overcome the errors in the position of the system, the data from LiDAR sensor can be used along with the odometry data in a way to improve the localization of the system. The LiDAR data uses the Time of Flight (ToF) where the emitted light beam from the sensor hits the surface and is reflected back to the source. As the speed of light is known, the distance of the surface from the source is obtained.

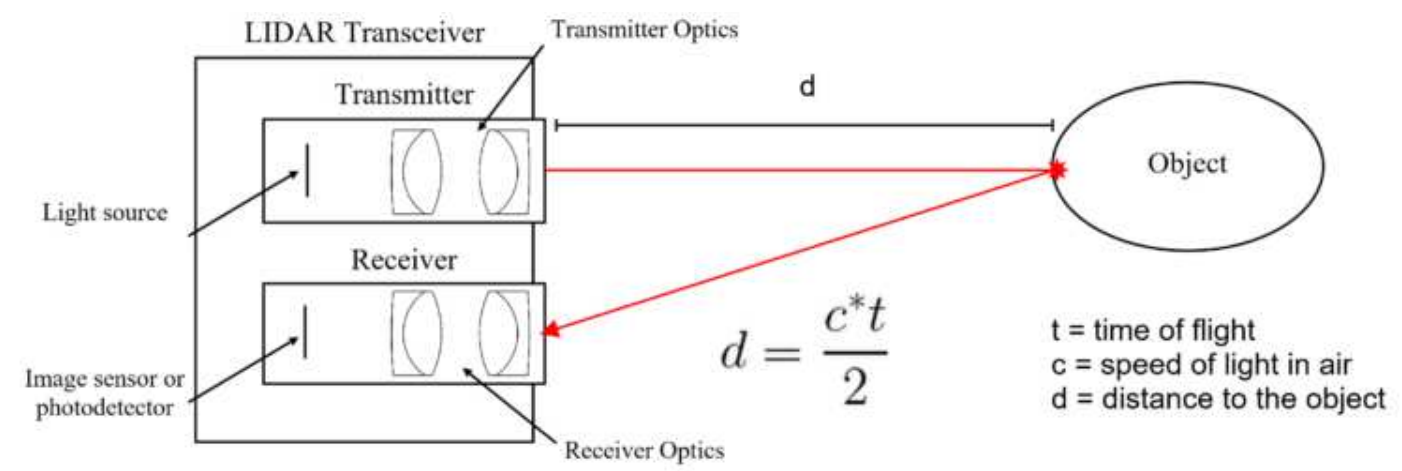

Fig. 2. LiDAR principle [1]

Object detection and recognition is a vital task for the robot as it can be helpful in the detection of the target objects as well as the presence of obstacles on the robot's path. The use of a camera will not only help detecting objects, but also provide a vision for the system. The working is not attained in a single step but it involves a sequence of steps. The robot has to be trained priorly with the object before it can be put to use. Additional care has to be taken while performing the training of the object to the robot as the image of the object during training is stored in the robot memory and it has to look for the object in the real-world environment. Improper training will result in less efficient working of the robot as it will reduce the accuracy of the object detection. The detection of tennis ball in a real tennis court is one of the challenging tasks. The hindrances that pose a threat for the detection of the ball in the tennis court are a) the ball located at a distance from the source will occupy less pixels b) some of the balls will be located in blind spots and c) finally, there may be objects with similar shape and colour of the tennis ball in the surroundings [10].

One of the common ways of detecting [8] the tennis ball is the using the algorithms based on the geometric model of the ball. Some algorithms like Circle Hough Transform and Gradient Vector based are used for detection of the ball based on its geometry. However, these techniques 
have a drawback - when the ball is located at some distance, it lacks a circular geometric model. In a way to overcome the drawbacks of the geometry-based approach, learning-based detection algorithm is proposed in this work. The proposed learning-based algorithm methods comprises of two steps: a) Region of Interest (ROI) extraction and b) classification. Blob detection algorithm can be used for extracting the region of interest from the camera image and a cascade classifier based on the Local Binary Pattern (LBP) feature can be used for the classification process. The object detection problem involves a lot more of computation process and it requires additional microcontroller board with large computation power and memory. For this, the Nvidia Jetson Nano is preferred to take over the computation process as the Arduino board is not capable of performing the computations required for this process. OpenCV can be used for the implementation of the ball detection process [9].

Conclusions. Thus, the design of four-wheeled mobile service robot with the ball collecting mechanism, which can help the user with picking up balls from the tennis court is proposed. The different operating modes of the robot are proposed for the effective work of the robot. Self-localization of the robot can be achieved with the odometry and LiDAR data using sensor fusion and the object detection is performed by OpenCV platform. The navigation of the robot is explained with the implementation of the $\mathrm{A}^{*}$ algorithm due to its short computation time for determining the path of travel and also the ability to avoid the obstacles during its manoeuvring in the tennis court. A semi-autonomous mobile robot is developed and its work is demonstrated with the help of a smartphone, which can be implemented to the proposed above mobile service robot for controlling its movement wirelessly. The working range of the robot is within the sufficient distance, which allows the use of Bluetooth technology to transmit commands to the robot.

Acknowledgements. This article was created thanks to the KEGA project support: 010TUKE-4/2020 Implementation of new knowledge and innovative approaches to the process of teaching robotics in line with Industry 4 and KEGA project support: 004TUKE-4/2021 Development of innovative teaching materials for learning multi-agent robotics.

\section{References}

1. M. Adams, S. Zhang, L. Xie, "Particle Filter Based Outdoor Robot Localization Using Natural Features Extracted from Laser," International Conference on Robotics \& Automation, 2004.

2. X. Zhang, X. Li, X. Zhang, "Automatic Docking and Charging of Mobile Robot Based on Laser Measurement," 5th Advanced Information Technology, Electronic and Automation Control Conference (IAEAC) |, 2021.

3. S. Wang, G. Xu, T. Liu, Y. Zhu, "Robust Real-time Obstacle Avoidance of Wheeled Mobile Robot based on Multi-Sensor Data Fusion," 5th Advanced Information Technology, Electronic and Automation Control Conference (IAEAC), 2021.

4. H. Li, Q. Zhao, X. Li, X. Zhang, "Object detection based on color and shape features for service robot in semi structured indoor environment," International Journal of Intelligent Robotics and Applications, 2019.

5. C Astua, R Barber, J Crespo, A Jardon, "Object Detection Techniques Applied on Mobile Robot Semantic Navigation," 2014.

6. C.-H. Y. Tsung-Han Tsai, "A robust tracking algorithm for a human-following mobile robot," The Institution of Engineering and Technology, 2021.

7. S. V. Krishnan, V. Singh, P. Shah, H. D. Shukla, A. Yadav, S. Saha and G. Panampilly, "Development of an RFID-Based Semi-autonomous Robotic Library Management System," in International Conference on Automation, Control and Robots, 2020.

8. G. Csaba, L. Somlyai and Z. Vámossy, "Mobil Robot Navigation Using 2D LIDAR," IEEE 16th World Symposium on Applied Machine Intelligence and Informatics, 2019.

9. G. Jiang, L. Yin, S. Jin, C. Tian, X. Ma and Y. Ou, "A Simultaneous Localization and Mapping (SLAM) Framework for 2.5D Map Building Based on Low-Cost LiDAR and Vision Fusion," 2019. 
10. D. U. Rijalusalam and I. Iswanto, "Implementation Kinematics Modeling and Odometry of Four Omni Wheel Mobile Robot on The Trajectory Planning and Motion Control Based Microcontroller," Journal of Robotics and Control (JRC), 2021.

11. D. H. T. Kim, T. N. Manh, C. N. Manh, N. D. Nguyen, D. P. Tien, M. T. Van and M. P. Xuan, "Adaptive Control for Uncertain Model of Omni-directional Mobile Robot Based on Radial Basis Function Neural Network," in International Journal of Control, Automation and Systems 19(X), 2021.

УДК 621.865 .8

\section{Рудольф Янош, Срикантх Мурали}

\section{КОНСТРУКЦІЯ РОБОТА ДЛЯ ЗБИРАННЯ М'ЯЧІВ}

Автоматизачія сервісної діяльності поступово поширюється на сферу спортивного обладнання, щяо дозволяє автоматизувати рутинні діï. У иій статті описано конструкиію робота для збору м'ячів на тенісному корті.

Проєктування автоматизованого обладнання є мультидисииплінарним завданням, що об'єднує конструювання шасі робота, механізму, що виконує основні функиії, розробка навігаційної системи та системи машинного зору.

Існує кілька аналогічних типів роботів, у яких переважно використовуються колісні шасі. У найпростіших роботів інтелектуальна система збирання м'ячів полягає лише у випадковому переміщенні робота навколо визначеного простору. Більш досконалі аналоги описують простір руху. Механізм збору кульок в основному реалізується за механічним принципом. Унаслідок різноманітності конструкцій сервісного робота для збору м'ячів у цій статті обрано шасі з конкретними параметрами.

У статті розглянуто основні ключові етапи проєктування робота для збору м'ячів. Завдання роботи полягає в розробиі сервісного робота, корисного для людей, які займаються тенісом, оскільки вони витрачають багато часу, збираючи м'ячі, розкидані по полю. Це також зменшить витрати зусиль гравия. Завдяки иьому він може більше зосередитися на своїй тенісній практиці. Запропонована концепиія чотириколісного мобільного робота для збору м'ячів з тенісного корту. Робот здатний до самостійного маневрування. Управління роботом можна здійснювати бездротово із застосуванням технології Bluetooth. Робот управлясться платою мікроконтролера Ardиіпо Unо R3 разом 3 такими датчиками, як LiDAR, ультразвуковий датчик, датчик ивидкості, інфрачервоний датчик, системою камер. Датчики на роботі можуть використовуватися для пошуку робота, а виявлення тенісного м'яча можна досягти за допомогою алгоритму виявлення об 'єктів на основі OpenCV. A *.

Стаття є оглядово-інформачійною.

Ключові слова: чотириколісний сервісний робот; об'єднання датчиків; робот для збирання м'ячів; мікроконтролер Arduino Uno R3; бездротове управління; технологія Bluetooth.

Jánoš Rudolf - Associate Professor, Technical University of Kosice, Faculty of Mechanical Engineering, Department of production systems and robotics (Park Komenskeho 8, 04200 Kosice, Slovakia).

E-mail: rudolf.janos@tuke.sk

ORCID: http://orcid.org/0000-0002-5754-9278

Srikanth Murali - Student of engineering studies, Technical University of Kosice, Faculty of Mechanical Engineering, Department of production systems and robotics (Park Komenskeho 8, 04200 Kosice, Slovakia).

E-mail: srikant.murali@student.tuke.sk 